\title{
Contribution of Educational Management to Optimal Service of Educational Development
}

\author{
Suharsimi Arikunto \\ Universitas Ahmad Dahlan Yogyakarta
}

\begin{abstract}
Education has a momentous and influential role in developing this country. The specific function of educational management may not be fully depended on the central government. In line with local autonomy era, local government (municipality) must also be able to initiate and play its extended role in order to enhance the educational quality at the local level. On the other hand the existence of higher education institutions at local levels, in particular those offering educational management or concentration on educational policy management, have to be able to develop their competencies to collaborate with the municipal educational offices towards further development and improvement of the educational quality at the local levels. This paper will explain several ways that can be done by the Educational Management or Administration in collaboration with the Municipal Educational and Cultural Office to initiate and play its extended role in order to enhance the educational quality at the local level.
\end{abstract}

Key words: educational management, educational quality.

\section{Introduction}

This paper related to educational management as parts of educational service. Educational service is part of government duty stated in the 1945 Constitution Preambule. Service given to the public according to Jazim Hamidi dalam Kurniawan (2007) is known as public service, which can be grouped into three categories, covering: first, primary service or minimum service, the most basic, such as service in citizenship, health, education and economic. Second, secondary service yet specific ones. Third, tertiary service, covering service which are nor directly given to the public.

It is the state responsibility to meet the people basic needs in terms of health, education and basic administration such as citizenship. However, it is not only in terms of delivering service which matters, but also in terms of quality of the service delivered. However, such responsibility is questionable in this area of decentralization. There are problems in the operationalization of educational management in the Regential/ Municipal Office of Education and Culture.

In this publication, The Fund for Peace (FPP), an American non-profit organization report that a nation is considered successful if it is capable of, among others, providing good public services. According to the FPP,
Indonesia has not been capable of doing such thing (Kompas, June 20, 2012).

Many field studies have already proven that an education affairs Indonesia must still work hard to solved problem related to educational management. Many complain have been addressed to educational governance, such as incomplete data, complicated bureaucracy, to mention some.

Cornoy (2009) has reported data on educational governance, which he believe as one of important aspect for educational reform. Educational governance or educational management does not only concern administration or bureaucracy, but also concerns three important aspects: educational management system, educational management organization, and educational human resource.

Educational reform is very important as well as strategic to perform in order to create good educational governance, which, in turn, to promote good educational service in this country. Once it has been achieved, any complaint, worry, and dissatisfaction towards education-related services can be eliminated.

Ideas to be presented in this paper will deal with dissatisfaction and anxiety of our students looking for materials, which are necessary for completing their research, such as final reports and thesis. A research 
of J. F. Senduk (2008) in North Sulawesi Provinces on educational policy-making reveal that researchers on educational policy were often faced with difficulties in finding data and information related to educational management.

The similar problem was also evidenced by Bambang Hadi Purnama (2007) in doing his dissertation on improving bureaucracy performance at Educational Office of Malang

Municipality, in collecting data and information of the educational management of the municipality due to the lacking details of the educational management.

Pursuant to act No. 14/2005 on Teachers and Lecturers: Government Act No. 60/2009 on Education, one of duties that lecturers must do at their universities is to help their students solve problems, in addition to solve problems faced by related educational institutions.

\section{Discussion}

Ideas on Tasks and Functions at Municipal/ Regencial Educational Office

Systems of management of national education in Indonesia have experienced fundamental changes since the 1998 reform.

Previously, the educational management system in the country was centralistic so that all policies were made by the central government. The centralistic educational management has caused gaps in educational development of the country because it could not accommodate differences, diversities, and interests of localities, schools, students, and tended to ignore people participation in the educational processes (Ministry of National Education, 2002).

However, changes toward decentralization, which is popular with the term 'local autonomy', have not always given positive results to the educational matters, in particular those related to institutional organizations responsible for managing the educational service at local levels. In the organizational structure of the Ministry of Education and Culture before the local autonomy era, major tasks and functions of each municipal/regencial office of education were subtle and welldefined. In the local autonomy era, the structure varies from one place to another, and so do the hierarchies. Senduk's (2008) and Bambang Hari's (2007) findings have strengthened the assumption the author has already mentioned above.

Organizational changes at the municipal/regencial education offices may also relate to the differences in interpretation of what local autonomy means. Local autonomy is sometimes wrongly defined as a differences in the educational management office between one municipality to another, according to the local needs. This rational leads to the differences in ways of organizing and establishing the organizational major tasks and fuctions.

Several studies (Agus Dwiyanto, 2006) even found that tasks and functions of educational office in different municipalities/regencies were translated differently. Tasks and functions in human resource development in particular municipal offices were differences from tasks and functions in personnel and curriculum, even though they were at the same office.

It is possible that tasks and duties of a department at one educational affairs office is different from the same department at the other office. However, there must be an exact standard in order to create good educational governance. One of ways is by providing good services in the educational management. There may be some mismatches in the management of the tasks and functions, which those who are responsible have not completely understood how to perform. The ambiguity of tasks and functions encourage individual and organizational performance toward misled situation. In this context Andrew (2010) writes that the performance of educational management is poorly structured so that it is difficult to expect good public service in educational management Good educational management is necessary to give response to changes in order to create better educational services and development.

As Amstrong (2011) writes: "There has been a growing literature concerning the teaching of management education and techniques. This has occurred against the backcloth of the managerialist underpinnings of contemporary 
organizational practice, and has led some to suggest that a critical for management educations is required in order to challenge its education changes."

The holistic changes in educational management to respond to the changes in educational situation need support from strong and good educational organization. However, what have happened are poorly managed educational organizations, as proven by poor tasks and functions definitions at the educational office at the municipalities / regencies.

An example of the above-mentioned phenomenon is a research lecturer at a university who visits the Municipal Office of Education and Culture to get information about how many subject teachers, how many kinds of subjects taught, and how many persons who have promoted to IV/B level. The answers obtained from the Office are unclear and complicated, resulting in the lecturer's dissatisfaction.

Research for thesis the students have already done mainly focused on the school management, including principal leaderships and supervision. Only few of the students and their supervisors draw attention to how the personnel at the educational affairs offices perform. I believe that those who are concerned with educational management need to tackle seriously important issues such as curriculum, students, human resources, facilities and other aspects. A good quality school administration needs to be best served by the Municipal/Regencial Office of Education and Culture, by improving functions and duties of unit or department through expert service with their theoretical background.

While every policy must be occupied with code of conduct and other instruments in order to ensure its implementations, there will be a time when lacking personnel due to workloads cause problems. Therefore, individuals whose expertise backgrounds are in management theories need to get involved in completing the jobs in order to create a strong networking between concerned parties. The involvement should be realized by lecturers and students through collective implementation of Higher Education Tridharma.

\section{Ideas on Educational Personnel at Municipal/Regencial Educational Office}

Educators or teachers at school become the key role to educational success, helping the school make an optimal achievement (Suharsimi, 2008, Depdiknas, 2002). To this end, educational personnel must be well-informed on the condition of each individual teacher such as workplace, workloads to be completed on weekly basis, additional tasks to be delegated and other information. With these comprehensive information, head of educational office at municipal/regencial level can make a planning and follow-up action should there be thing necessary to be rearranged in order to help the students attained their best performance. For example, teachers outnumber in particular subject at one school can be transferred to other schools by temporary service in schools lacking of teachers in that particular subject.

One among innovative is not to fragment the teachers according to their teaching level. For example, a secondary school, which still lacks of qualified teachers, may ask for help from high school to provide its teachers. This strategy does not only give more opportunities to the secondary school students to develop, but also helps the teacher obtain teaching hours limit required for getting a teacher's certificate.

Another problem relates to lacking competencies of teachers in completing their tasks properly. The problem needs to be tackled immediately to bring on necessary solutions. If the competency enhancement occurs, institutions working on teacher's accreditation and training, such as Centre for Educational Quality Assurance (LPMP), will not be disappointed due to the mismatch between the teachers sent for training and the demand in the real world. To get the desired target, that is improved teachers' capabilities; training agencies must have mutual understanding and agreement with the Municipal/Regencial Office of Eduation, in particular the Personnel departement in collaboration with the Curriculum Department. Well-managed teaching personnel are important to help realize the teachers' certification. 
When the Educational Unit-based curriculum (KTSP) policy implemented in 2006, most teachers found difficulties in its implementation. They complained that, while the Competency-based Curriculum (KBK), which was inaugurated in 2004, has not been completed, the authorities have given them heavier loads. This problem raises my concern about lacking socialization of the curriculum so that most of the implementing teachers did not know what to do with that. These teachers should have been informed that the Educational Unit-based Curriculum (KTSP) must be made available because it is the consequence of the Competency-based Curriculum (KBK). If only the personnel of the Curriculum Department of the Municipal/Regencial Office of Education were involved in the policy implementation, and then socialize the curriculum well, the teachers would have not had such complicated problem, or even there would have not been dispute or problem at all. Our responsibility as experts and close-watchers of educational management is to actively participate in the public policy-implementation concerning personnel activities at school. The lack of numbers of teachers at certain subject at particular school or educational level can be compensated by the teacher surplus found at other schools and/or educational levels. There may be some policies enabling this system to occur, or there may be ideas from some people but they may be not brave enough to raise their concern or do not know how to realize it.

The similar arrangement also applies to non-teaching personnel, either academic or administrative staff. A possible scenario that may happen to the school is that it has some personnel who have the same responsibilities, making the school less efficient by having too many people for the same jobs; but on the other hand, there is another school that still lacks of personnel with such qualifications. For instance, person responsible for filing department is not available so that workloads will be at the expense of the available staff, who sometimes are just unable to complete the tasks due to the mismatch between educational background and experience and the tasks in hand.
A study result done by LP3M of Muhammadiyah University Yogyakarta (2010) under the SCBD Project in Yogyakarta Province reported that the Provincial Educational Office still lacked of competent staff in educational management, while there was an excess staff in educational evaluation. This situation made this bureaucratic institution difficult to manage the educational organization in the Yogyakarta Province.

At present there are approximately $300,000 \mathrm{IV} / \mathrm{a}$ teachers who still have difficulties in meeting the credit requirement for teaching profession so that they are unable to be promoted to the IV/b level. In spite of may belief that many lecturers in educational management have been involved in the promotional efforts, much better agreement and understanding are deemed necessary to help these teachers meet the requirement.

\section{Ideas on Educational Facilities Management}

Mismatch in distribution of educational facilities does not only occur at difference educational level but also between schools at the same educational level. I used to visit an elementary school, which had four torsos (human body modeling for educational practices), thanks to the school's status as a site for several pilot projects. Each project facilitated torsos to improve this school's quality. All of these torsos are still wrapped in about finding difficulties when re-stored them after using for student practice. It was very ineffective that the school did not use these torsos.

If personnel at the Facilities Department of the Municipal/Regencial Education Office cooperate well with those at the curriculum Department, they may take initiative to distribute these torsos. It would have been better if these torsos were given to other schools whose personnel had already known how to use them. Furthermore, the personnel at the Curriculum Department may ask for a help from local higher education institutions to train and guide the teachers, in particular those teaching natural sciences, how to use the torsos when explaining about human bodies in their classrooms. 
Similar distribution can also apply to other school facilities, such as library books. In my experience, I have already visited a school with many Indonesian Language dictionaries while other schools do not have them at all. These dictionaries cold then be shared with other schools that still had only few. The use of the dictionaries had not been effective because students only read them to find word terms. Such distribution strategy needs policies from the Facilities Department of the Municipal/Regencial Education Office. Most school principals still show their objection to lend their books to other schools. It is important for them to learn goodwill as taught by Pancasila: helping others obtain the mutual betterment and taking all the deeds for granted.

Another important issue, which relates to the school facilities, is that most of the schools have plenty of used or broken benches, chairs, and other furniture's. At the time before school committee was available, the used facilities could not be repaired because the schools lacked of financial resources. I think the present existence of school committee could facilitate a breakthrough. For example, mediated by the school committee, elementary or secondary schools can start partnership with other educational institutions, i.e., vocational high school. This partnership is formulated at meetings between the schools that suffered from facility damage and the vocational schools with skilled resources to repair the facilities.

The skills given to the vocational school students can be useful for helping the non-vocational schools solve the problems related to broken facilities. Students of vocational education are taught to have four competencies: to scale, cut, polish, and join. Instead of using new materials, these competencies can also be taught using broken benches, chairs, tables, or other furniture's owned by other schools.

The broken furniture's can be valuable for them to exploit their abilities before graduating the school. Furniture reparation by the vocational students, of course, will not be free of charge. However, to avoid financial reporting responsibilities at the stake of the general schools, they can compenstate the skils by providing job opportunities. This kind of co-operation can take the form of individual partnership. Once the partnership has taken place, it will benefit the vocational sutdents since they may learn how to solve problems, such as in selecting the woods for assembling prosess. In addition, the vocational students may get used to repairing the used facilities. Furtheremore, they can have more opportunities to train themselves working.

Students of Educational Management also attend Library lecture, a fact that many may not aware. Graduates of the Educational Management concentration actually have capabilities in the book collection management, even administering libraries with the skills they have learned from the classrooms. In Indonesia many faculties or study programs have been offering general library program, not specializing in school libraries. The legal protection for the librarians have been promulgated through the Minister of National Education Act No. 25, which has been in effect since 2008. Therefore, it is now the time for the Educational Management Study Department should open study program for school librarians. The schools definitely need the graduates from this discipline.

According to Samuel C.Certo and Trevis Certo (2005), decision-making should be taken long before the planning process begins. Such initiative is also known as need assessment. In preparing a building facilities planning, the Municipal Educational Office in Mataram has experienced a plan in the forms of "Building Album". This plan did not relate to the building projects for elementary schools, secondary schools, and high schools as has been routinely taken by the government. "Building Album" was implemented by the Ministry of Public Works by the request of the Ministry of Education. The album contained building conditions, which described five main elements: (1) floor, (2) wall, (3) door and window, (4) roof, (5) ceiling. Each of these elements described the real condition and the estimated renovation and cost for development. According to this description, the collaboration between the schools and 
the local Educational Office would allocate the necessary funding's

Since now there has been School Committee in each school, they can tackle building-related problems as in the experience of Mataram Educational Office. If necessary, the schools can co-operate with vocational highschools where skills are available to help inspect the school buildings and needed facilities. This cooperation-based development can take place at holiday seasons so that it will not disturb the educational activities of the students.

\section{Ideas on Conceptual Misconduct}

Monitoring and evaluation are also known as "money", which is derived from the acronym of these two terms. Most projects or routine activities nowadays apply "money". However, it only use evaluation instruments since usually monitoring instruments do not exist. The followings are important terms that one should understand and comprehend further:

Monitoring is an activity of eyewatching the implementation of a plan compared to the plan. Such activity includes steps, personnel who implement, time necessary, perceived funding's, etc. In the monitoring, these aspects should be the very prominent ones so as to prevent any exceed fund.

Evaluation is an activity eye-watching purposes achievement for a certain period. For example, as the process has been lasting for three months, it is important for the project actors to evaluate whether it has been done, i.e., a quarter of the whole part, as previously expected.

In the perspective of public policy, the monitoring and evaluation activities have been a necessity, which begins with planning and ends with the policy evaluation, including educational policies. However, in practice, monitoring and evaluation activities were sometimes poorly performed and is only deemed as formality. A study by Andrew Armitage (2010) revealed that almost all developing countries do their monitoring and evaluation activities as no more than formalities and routines, so that their functions were considered insignificant for the works and qualities of the educational services.

In the monitoring and evaluation stage, the educational policy is intended to obtain feedback from the policy stakeholders, so that any hampering factor can be anticipated as early as possible. The way of collecting information of the programs can be performed by monitoring and evaluating. Turang (2002) suggests that monitoring is used for providing information at value premises necessary to give information of the policy performance. Through monitoring and evaluation, the educational office may have necessary information of the strengths and weaknesses, obstacles and new problems, whereas the information by means of questioners, interviews, field observation and archives must be relevant, reliable, and valid (Dunn, 2000).

\section{Implementation Educational Policy}

The very important issue in providing service on educational management to the community by the Municipal/Regencial Education Office is the improvement of capacity of the educational bureaucratic apparatus in relation with the implementation of the educational policy related to

educational service. Concerning the implementation of the educational policy, once a policy has been agreed and put into effect by the authorities, the policy must be ready for implementation to answer any challenge and opportunity, either from inside or outside the organization (Siagian, 1985). It is provided that the policy closely related to the impact or consequence of its implementation.

To implement the policy, fundamentally it can be stated that the implementation of the educational policy is very dependent on the ongoing condition of relationship between individuals and institutions. The more positive relationship between needs and obligations, the more effective the educational policy implementation will take place.

To guarantee the high level of efficiency and effectiveness in relation with the implementation of the educational policy, the policy product must be carried out in proper manner by the implementing 
units. It is because as the educational policy has been put into effect, it does not mean that educational problems faced by the policy-makers will be automatically solved, but they still need initial steps to be overcome. Field data have shown that initial steps before the educational policy implementation include the following:

Firstly, policy socialization. Socialization is a process in which participants (those who implement the process) learn and internalize values and norms in an organizational culture. In other words, before the educational policy decision is implemented, the Office initiates a socialization of the policy to its staff to give them information, understanding, ways and strategies to help all implementors in practice. It is a useful method to minimize different perceptions between the policy-makers and the parties who implement the policy. This activity is expected to keep the policy implementation on track as previously planned. Furthermore, periodical educational policy socialization by the implementing schools will be a good feedback to the Educational Office.

Secondly, facilitation. The next step, facilitation, is as important as socialization. Facilitation is provided by means of guidance and supervision in developing work plans to know whether the educational implementation works well as expected. The implementing schools will easily adapt, even fully adopt and implement any newly introduced educational policy when the guidance and supervision are performed properly, clearly and systematically. The outputs of the educational policy in relation with the advance and improvement of educational quality, efficiency, effectiveness, relevance and independence of the schools can be obtained optimally (Turang, 2002). In addition, impact or outcomes of the educational policy implementation on the advance and development of the educational life will be clearly defined so that community and schools as the policy stakeholders can enjoy the policy results, either directly or indirectly.

Thirdly, training for policy implementors. Training program helps individuals and organization to learn developmental process of the future work. It also helps motivate the policy implementors to work more properly. To make the operationalization of the new educational policy successful, a training must be given to the staff who implement the policy to complement their current capacity and skill. Training is very important for everybody, even is the ultimate need of the executives, implementors and operators. The better the quality of the trainees, the better their performance will be, which, in turn, the better the quality they will demonstrate along the organization. The raining needed does not restrict itself to the organizational works, but it also extends to the organizational objectives.

\section{Performing Service Mechanism}

Education has a significant and strategic role in developing this country. The role of educational management may not be fully relied on the central government. In line with local autonomy era, local government (municipality/ regency) must also be able to initiate and play its extended role in order to enhance the educational quality at the local level.

On the other hand, the existence of higher education institutions at local levels, in particular those offering educational management or concentration on educational policy management, have to be able to develop their competencies to collaborate with the municipal educational offices towards further development and improvement of the educational quality at the local levels.

There are several ways that can be done by the Educational Management or Educational Administration in collaboration with the Municipal/Regencial Educational and Cultural Office, covering:

a. Better cooperation between aggregates of the study programs and the Municipal/Regencial Educational and Cultural Office by creating a Memorandum of Understanding (MoU). The description of all programs' activities should be related to the plans of the study programs improvement in line with their annual accreditation, which then renewed through agreement with the Educational and Cultural 
Office.

b. Studies, researches or community projects by university lecturers and academics. The mechanism has been performed, but still needs improvement in the quantity and quality.

c. Establishment of ad hoc incubatory mediating bodies between the development of mediation will function as bridging for filling the gaps between the development of academic concept, practice, policy-making and policy implementation in educational affairs so that 'link and match' between academic world at the higher education level and practical world at the Municipal/Regencial Ecuational Office can be created.

d. Establishment of synergy between the Municipal/Regencial Educational Board, the Municipal/Regencial Educational Office, Higher Education, and other stakeholders, to take collective measures towards sustainable improvement of the educational quality at the local level.

\section{References}

Armstrong, P., 2011, Changing Management Control Strategies: The Role of Competition between Accountancy And Other Organizational Professionals, Education Organizations and Society, Vol. 10, No. 3., pp. 129-148. mitage, Andrew, 2010, "Toward Reflexive Practice For Management Education," The Journal for Critical Education Policy Studies, November 2010, Vol. 8.

Bambang Hari Prunama, 2007, Peningkatan Kinerja Aparatur Birokrasi Pendidikan, Disertasi Universitas Negeri Malang, Tidak dipublikasikan

Certo, Samuel C. and Certo S. Trevis, 2006, Modern Management 10e,
International Edition, New Jersey: Pearson Prentice Hall.

Cornoy, M, 2009, "Globalization and Educational Reform: What Planners Need to Know", The Journal of International Institute of Educational Planning, January 2009, Vol.2.

Depdiknas, 2002, Profil Perencanaan Dalam Rangka Desentralisasi Pendidikan, proyek Pengembangan Profesional Sektor sosial, Jakarta.

Dunn, William, 2000, Pengantar Analisis Kebijakan Publik, Yogyakarta: UGM Press Kurikulum Jurusan Administrasi Pendidikan, Fakultas Ilmu Pendidikan, Universitas Negeri Yogyakarta, 2009.

Laszlo, E, 2009, World Shift 2012, Veimont: Inner Traditions.

Luthfi J. Kurniawan dan Hesti Purpitosari, Wajah Buram Pelayanan Publik, Malang: Yappika.

Prpic, J., 2005, "Managing Academic Change through Reflexive Practice: A Quest for Nes Views," Research and Development in Higher Education, 28, 399-406.

Senduk, JF, 2008, Pola Pembuatan Kebijakan Pendidikan : Studi Kasus Pada Tiga Dinas' Pendidikan di Sulawesi Utara, Menado: Universitas Sam Ratulangi.

Siagian, Sondang P. 1985. Analisis serta Perumusan Kebijaksanaan dan Strategi Organisasi. Jakarta: Gunung Agung.

Suharsimi Arikunto, 2003, Laporan Konsultan, Development on Basic Education Project, Jakarta: Biro Humas dan Organisasi.

Turang, J. 2002. Pengembangan Kebijakan Pendidikan Tingkat Kabupaten/Kota Tomohon: Yayasan Mapalus Matuari Minaesa (YM3).

Peraturan Menteri Pendidikan Nasional nomor 25 Tahun 2008 Tanggal 11 Juni 2008 tentang pustakawan sekolah. 